\title{
Students' Needs Analysis on Genre-based Listening Material at University Level
}

Edi Trisno*, Emzir, Ilza Mayuni

Post Graduate Program, Universitas Negeri Jakarta, Jalan Rawamangun Muka, East Jakarta, 13220 Indonesia

Corresponding Author: Edi Trisno, E-mail: edi.trisno@fbs.unp.ac.id

\section{ARTICLE INFO}

Article history

Received: January 20, 2018

Accepted: March 19, 2018

Published: July 01, 2018

Volume: 7 Issue: 4

Advance access: May 2018

Conflicts of interest: None

Funding: None

\begin{abstract}
The present paper explores students' needs analysis on genre-based multimedia listening material for the development of students' listening skills for English department students at university level. This research was a part of research and development conducted based on both qualitative and quantitative methods. This needs analysis cover necessity, lack, and wants. Information on necessities is taken from the curriculum of English Department of UNP, users, teacher books, and other relevant documents. To obtain the data, the English department students of FBS Universitas Negeri Padang in Indonesia were given the questionnaire in the preliminary study in obtaining students' needs. The questionnaires were used to obtain the information on students' necessity, lack, and want. The research findings show that the genre-based material for listening is needed to develop students' listening skills. For the media, students also need multimedia material which help them in understanding the situation and information.
\end{abstract}

Key words: Genre-based, Listening Skill, Listening Material, Multimedia, Needs Analysis

\section{INTRODUCTION}

Listening is one of the subjects that get a big influence from the development of multimedia technology. This is due to several factors. First, the listening atmosphere, especially listening in English, with multimedia technology provides diverse sources relevant to second language learning contexts. Second, much of the research that has been done in the context of second language acquisition and computer assisted language learning (CALL) shows the advantages of using multimedia over conventional media use (Lebedev, et al, 2017). Among these advantages is the combination of media in helping learners understand new language inputs easily so that the needs and interests of these learners can be maintained (Asma, 2013. p.49). Third, multimedia enables learners to have opportunities to interact, get feedback as soon as possible, improve learning autonomy, and get simulated in real situations and experiences through video, audio, and graphics (Ketsman, 2012, p 12). Fourth, multimedia tools, both software and hardware, serve as an important motivator in the process of language learning because the material delivered through multimedia can bring authenticity into the classroom situation, so as to strengthen the direct relationship between language classes with the outside world (Brinton, 2001, p.459).

Unfortunately, the progress of learning listening supported by this new multimedia technology is responded by the limited circumstances. The results of the initial observations made by the researchers showed the low interest of lecturers in listening subjects in using multimedia-based learning and developing teaching materials based on technology. This learning process is dominantly conducted in audio laboratories with tapes and tape recorders as the main media. The use of video material is only a variation. Furthermore, the use of multimedia-based materials is almost non-existent. Thus, the teaching materials used tend to be monotonous because it only comes from one or two source books. While the latest learning demands, especially learning listening, is the variety of material resources used and the variety of genres taught so that learners will not have difficulty in understanding the texts that appear in real situations.

To solve this problem various things can be done, such as updating learning listening designs, maximizing the use of the latest media, and designing learning models based on the use of the latest technology, especially multimedia. The development of teaching and learning models based on genre and multimedia is one solution that can be offered and is believed to improve students' listening capabilities because the application of this model will use various learning materials and media, especially technology-based media such as computers.

Currently, some researchers have reported that the development of technology is beneficial to the changes of language learning (see Dost, Bohloulzadeh, Rahmatollahi, 2017). Language learning are utilizing technology, especially by utilizing multimedia technology (Ketsman, 2012, p.1). Moreover, various research results in the field of foreign language learning shows that language learning that 
utilizes multimedia technology has a positive impact on the progress of learners. Gilakjani, Ismail, and Ahmadi found that multimodal learning models have a positive impact on language learning because this model provides opportunities for learners to practice through experiential learning, to improve learners' motivation \& learning outcomes, encourage greater interaction, emphasize individual needs, and liberate learners from dependence on one learning resource (Gilakjani, Ismail, Ahmadi, 2011). Similarly, Chang and Lehman found that the learning of foreign languages by using interactive multimedia program gives a significant impact on the improvement of learning outcomes of learners and there is no interaction between the types of learning motivation with the learning outcomes of learners (Chang \& Lehman, 2012, $\mathrm{p}$ 81). However, those researchers did not explore what should be given to the students in learning listening skills.

Empirically, the results of research in the utilization of multimedia technology in learning listening are very encouraging (Al-Hammadi, 2011; Asma, 2013; Sadeghi, Hassan, Noory, 2014). Al-Hammadi (2011) and Asma (2013) focused their research on the use of multimedia and its impact on the learners. Then, Woottipong in Thailand only focused on the impact of the use of video material on learning listening skills (Woottipong, 2014). On the other hand, Sadeghi, Hassan, and Noory report that genre-based listening inputs have a positive impact on listening skills of Iranian students who learn English as a foreign language. However, those research findings did not report what students' need on those multimedia and genre-based materials. Thus research and development of teaching material models which based needs analysis on those matters is very necessary, since English should be designed based needs analysis (Petrus, 2012).

In addition to the theoretical and empirical reasons presented above, there is another reason that makes this research more rational. The reasons are institutional reasons. State University of Padang (UNP) has developed an online learning system based on Learning Management System (LMS) using Moodle software. Lecturers in UNP at this time is recommended to use e-learning learning system is more optimal in providing materials and tasks that can be accessed by students at any time.

Based on that reason, the present paper, as part of the research development, focuses and aims at providing the information on the needs of students on listening materials based on genre and multimedia in English. To meet this aim, the following research problems are formulated as follows:

1. What are the necessities of the English Department and the user on listening skill?

2. What are the lacks of listening skill needed by the students?

3. What are the wants of the students on listening material based on genre and multimedia?

By answering those questions, this paper has the goals to present the needs of the students on the listening material which cover the necessities of the institution and stakeholders, fulfill the lacks and wants of the students on genre-based and multimedia listening material.

\section{LITERATURE REVIEW}

\section{Teaching Materials}

Teaching materials are a key component in almost all language learning programs. Teaching materials, whether in the form of textbooks, materials prepared by institutions or self-prepared materials, generally serve as a basis for language input in language exercises in the classroom. The forms of these teaching materials may be (a) printed material, such as books, workbooks, worksheets, or reading materials, (b) in the form of non-print materials, such as cassettes or audio recordings, video, or computer-based materials, and (c) material consisting of both printed and non-printed material, such as material originating on the internet. In addition, materials designed not for learning purposes, such as magazines, newspapers, or television shows may also have a role in the language learning curriculum (Richard, 2001, p. 251).

Learning materials should be closely related to the profile of learners, learning objectives, and our beliefs as a teacher. It means that teachers should be able to develop clear principles and procedures in using existing learning resources and create their own teaching materials. With regard to the role of teaching materials, Cunningsworth (1995) identifies that there are several important roles of teaching materials in language learning, they are: a). as a source for presentation material (oral and written), b). as a source of training activities and communicative interaction for students, c). as a reference to grammar, vocabulary, pronunciation, etc. for students, d). as a source for stimulation and ideas for activities in the classroom, e). as a syllabus, which reflects predetermined learning goals, and f). as a support for less experienced teachers who want to achieve a confidence in teaching (Cunningsworth, 1995, p. 7).

There are several considerations in developing the material put forward by Graves (in Cunningsworth, 1995). The first consideration is from the student aspect. In this case, materials should be made relevant to their experience and background, the material must be relevant to their target needs (outside the classroom), and the material should be relevant to their affective needs. The second aspect is learning. In this case, the material should contain the process of discovery, problem solving, and analysis. Materials should also develop specific strategies and skills. The third aspect is the language. The material should target the relevant linguistic aspects (grammar, language function, vocabulary, etc.). The material should also integrate the four language skills (listening, speaking, reading, and writing). The material must use authentic texts. Then, it should have social context. In this case, the material must also focus on cross-cultural and develop critical social awareness. The fifth aspect is the type of activity. Materials aim for authentic activities (tasks), varying roles and groupings, and varying activities and goals. The last aspect is the material itself. The material itself must be authentic (in the form of text or real objects), and vary (print, visual, audio, etc.) (in Cunningsworth, 1995, p. 156). To achive those criteria, this research was conducted to collect the information what should be included in the listening material for the students that relevant to their needs, (necessity, lack, and want). 


\section{Genre-based \& Multimedia in Language Learning}

Genre-based language learning is thriving in Australia through the work of educative linguistic experts and educators working for a group of underdeveloped students in education. This approach is now widely used in educational settings in many countries, including Indonesia.

There are three basic assumptions underlying this genrebased approach. First, learning a language is a social activity. Halliday explained that learning language as 'learning to mean and to expand one's meaning potential' affects three things: students learn language, students learn through language, and students learn about language. The second assumption is that learning will work effectively if teachers communicate explicitly what they expect from learners. A genre-based approach is very concerned with providing learners with explicit knowledge of language. The third assumption is that language learning is a series of scattered developmental steps that address different aspects of a language. This is based on Vigotsky's ideas and Bruner's ideas (in Feez, 1998, pp. 24-27).

Multimedia is one form of technological developments that influence large enough toward the changes in foreign language learning system, especially learning English as a second language or a foreign language. It is indicated by the increasing number of teaching and learning process that uses this multimedia technology. Currently, many universities offer using various multimedia technologies in teaching language skills. There are some departments that use multimedia as a tool in the learning process and there are also courses that have made multimedia as the basis of development of materials for recovery, such as CALL (Computer Assisted Language Learning) courses but not in the listening course.

\section{METHOD}

This research was conducted for the subject matter at UNP. It was chosen as the scope of the study because UNP has provided e-learning facilities. This research uses Research and Development design $(\mathrm{R} \& \mathrm{D})$. The main purpose of this research and development is to develop an effective product to be used by lecturers and students in the course of Listening I in English Education Study Program of UNP. This type of research is believed to be appropriate for the purposes of this study. The use of R \& D is promising in education as it involves a close relationship between systematic program evaluation and future program development (Gall, Gall, \& Borg, 2003, pp. 569-570).

The research methods used in this research and development are through surveys that are used to identify the needs of lecturers, students, stakeholders on teaching materials that are relevant to the demands of the curriculum and supported by the latest theories of English learning. However, the present papers is focused on the needs of the students. This method is appropriate to be used with the consideration that the respondents involved are quite numerous and the items to be identified also vary.

\section{Instrument \& Source of Data}

Need analysis is done by analyzing the documents related to learning listening. The first document in the analysis is the curriculum of English Education Study Program. This is done to see the position of the subjects listening in the study program and description for each course. Thus, the direction of learning listening can be well described. The second document in the analysis is the secondary school curriculum. It is intended to get a proportion of listening learning at the secondary school level. Since the graduates of this study program will become teachers in high school, they must also understand the subject matter of listening in high school.

The next step is to do a lack analysis or problem analysis (Lack) faced by students in learning to listen. To obtain data regarding the analysis of these shortcomings, 26 students were asked to fill out a questionnaire containing the problems they encountered as they followed the listening lesson. The samples were selected by using cluster random sampling. Questionnaires are focused on the teaching materials used, especially on the three aspects of sub-skill listening skills, the type of text, and the type of task/activity.

The first aspect of the lack is issues relating to the skills/ sub-skill of listening in English. The problems students encounter with these listening skills/sub-skills are expressed by using 28 statements. The statement used to reveal the problems faced by the student regarding the skills/sub-skill of listening.

The research instrument is a questionnaire developed with the basic principles taken from the genre approach that English learning emphasizes the understanding of a particular oral text or genre. Learners should be able to recognize the social function of a text, text structure, and lexicogrammatical elements of the text. The genre-based approach is supported by the use of multimedia. The basic principles derived from the use of multimedia are the teaching materials presented using various media, ranging from audio media, audio-visual, to the use of software supported by the use of multimedia computers. Instrument validity and reliability needs to be done that the instruments used are really feasible and appropriate to obtain the desired data. All the questionnaires used in exposing student problems in this study tested the validity of construct by using expert judgment.

\section{RESULTS AND DISCUSSION}

This study focuses on the analysis of the needs of students and lecturers on the teaching materials of the Listening I subjects of The English Education Program of Universitas Negeri Padang (UNP) that covers three things, namely (a) necessities, (b) lacks, and (c) wants. Analysis must be done to see what the teaching material should be listening to. Analysis of deficiencies (lack) is done to see the problems faced by students. Analysis of Wants is done to see what things are deemed important for the students to be loaded in teaching material.

\section{Necessity}

The first element of needs analysis is necessity. Information about the requirement was obtained by analyzing the curriculum of English Education Study Program of UNP and analyzing the needs of the users. Here is the result of analysis of both elements. 


\section{Analysis of the curriculum of English language education}

Based on the result of document analysis on the curriculum of English Language Education Program of FBS UNP, listening is an important language skill element should be mastered by the students. It is indicated by some listening courses that must be followed by students, i.e. Listening I, Listening II, and Advance Listening. The subject of Listening I is offered to students with the purpose of giving knowledge and skills to the students about: introducing oneself and others, leave taking, asking and answering questions, thanking, apologizing, complimenting, asking and giving help comments, facts and opinions, repetition, clarification, invitation, giving praise, showing doubts, amazement, likes and dislikes, using the phone conversation.

There are 3 kinds of text groups that students need to master in Listening I subject. The three kinds of text groups are, (1) interactive texts, such as dialogue about introducing themselves, asking places, asking circumstances, agreeing or disagreeing, 2) short functional text, such as announcements, advertisements, warnings, invitations, and (3) short monologue texts, such as people's descriptions, place descriptions, procedures for making/making things, or stories.

Based on the results of interviews with several lecturers of the subjects of Listening I, not all types of texts can be taught to students due to time constraints and credits. This course has a weight of 3 credits. This course is taught by 2 lecturers and taught 2 times a week for 2 hours (100 minutes) for 1 meeting. Unavailability of sufficient time to teach all types of text makes lecturers selecting subjects to the type of text to be taught. Selection is done by guiding the types of texts that have been taught during their time in high school and what kinds of texts should be taught in Listening II, in order to avoid repetition process so much.

From the above description it can be concluded that there is an obligation for the lecturer of the subjects of Listening I is to teach basic listening skills in English and also teach various kinds of simple text. However, the type of texts that will be taught is determined by the lecturer by taking the syllabus of the subjects of Listening I, Listening II and Advance Listening.

\section{Analysis of users' needs}

The need of users can be seen from the curriculum applicable in secondary schools, namely KTSP 2006 and Curriculum 2013. Based on the 2006 curriculum document analysis (KTSP), it was found that the purposes of learning English in junior high school are (a) the ability to communicate in English, in oral and written form which includes listening, speaking, reading, and writing. (b) the awareness of the nature and importance of English as one of the major means of learning, and (c) the understanding of intercultural and cultural interconnections and broaden the cultural horizons, so that students have cross-cultural insights and engage in diversity culture. The competency standard of English learning is to communicate in spo- ken and written English fluently and accurately in accordance with its social context. The standard of competence related to listening to English is to capture various meanings (interpersonal, ideational, textual) in various interactional oral and monologue texts, especially in the form of descriptive narrative, recount/spoof, procedure, report, and anecdote.

The objectives of learning English at senior high school based on the 2006 curriculum are: (a) to develop communication skills in English in oral and written form, including listening, speaking, reading, (c) develop an understanding of interconnectedness between languages and cultures and broaden the cultural horizon, so that students have an insight into the nature and importance of English as one of the major languages of learning. The competency standard of English learning is to communicate orally and write using the appropriate variety in a smooth and accurate way. The standard of competence related to learning to listen to English in high school is to capture the various meanings (interpersonal, ideational, textual) in various oral interactional and monologue texts, especially in the form of descriptive, narrative, recount/spoof, procedure, report, news items, anecdote, exposition, explanation, discussion, commentary, and review.

With regard to the text type, the results of the KTSP analysis show that there are 6 types of texts that should be taught to junior high school students and 12 types of texts that should be taught to high school students. The texts that should be taught to junior high school students are descriptive, recount, procedure, narrative, news items, and anecdote. The types of texts taught to high school students are descriptive, recount, procedure, narrative, news item, anecdote, report, explanation, analytical exposition, hortatory exposition, discussion, and review. The types of texts that are taught for vocational students are more diverse in accordance with the needs of each department.

The results of the analysis of the 2013 curriculum show that there are 5 kinds of text (monologue) that should be taught to junior high school students. The types of text are Procedure, Descriptive, Recount, Narrative, and Report. For SMA/SMK level, there are 7 types of written text (monologue) that should be taught to high school/vocational students. The types of text are Procedure, Descriptive, Recount, Narrative, Report, Analytical Exposition, and News Items.

Based on the above explanation it can be concluded that learning listening should contain about learning by focusing on the types of texts taught in secondary schools so that prospective students already have adequate knowledge and skills about listening to various texts. Teaching materials used should also support the creation of learning various types of text to the fullest.

\section{Lack}

The second component in the needs analysis is the analysis of lack. Information related to this analysis is explored by looking at three components, namely skill/sub-skill listening, type of text (genre), and type of task/activity. The following are the results of the analysis for the three components included in the lack. 


\section{Listening skill/sub-skills}

The first aspect of lack is problems with skills/sub-skill in English. The problems students encounter with these listening skills/sub-skills are expressed by using 28 point statements. The following table illustrates the student's response to the problems they face with regard to skills/sub-skill listening.
The table above shows that students are troubled with as great skills/sub-skill listening. This is evidenced by the 16 items of statements are in the High $(\mathrm{H})$ category and the 12 statement items are in the Medium category (Med). The overall average score is 2.83 and is in the High $(\mathrm{H})$ category. According to the students, listening skills/sub-skills that are

Table 1. Students' problems related to listening skills

\begin{tabular}{|c|c|c|c|c|c|c|c|c|}
\hline No & Skills/Sub-skills & $\mathbf{S}$ & ST & $\mathbf{O}$ & VO & Total & Score & Remark \\
\hline 1 & $\begin{array}{l}\text { Detecting meanings expressed in differing grammatical } \\
\text { forms/sentence types }\end{array}$ & 2 & 16 & 45 & 4 & 67 & 2.58 & Med \\
\hline 2 & $\begin{array}{l}\text { Recognizing communicative function of utterances, } \\
\text { based on situation, participants, goals }\end{array}$ & 1 & 20 & 36 & 12 & 69 & 2.65 & Med \\
\hline 3 & $\begin{array}{l}\text { Reconstructing or inferring situations, goals, } \\
\text { participant, procedures }\end{array}$ & 0 & 2 & 54 & 28 & 84 & 3.23 & $\mathrm{H}$ \\
\hline 4 & $\begin{array}{l}\text { Using real-world knowledge and experience to work } \\
\text { out purpose, goal, setting, and procedure }\end{array}$ & 5 & 24 & 27 & 0 & 56 & 2.15 & $\mathrm{Rd}$ \\
\hline 5 & Predicting outcomes from events described & 3 & 6 & 33 & 36 & 78 & 3.00 & $\mathrm{H}$ \\
\hline 6 & Inferring links and connections between events & 0 & 4 & 42 & 40 & 86 & 3.31 & $\mathrm{H}$ \\
\hline 7 & Distinguishing between literal and applied meanings & 3 & 20 & 27 & 16 & 66 & 2.54 & Med \\
\hline 8 & $\begin{array}{l}\text { Recognizing coherence in discourse, and detecting } \\
\text { main idea, supporting idea, given information, new } \\
\text { information, generalization }\end{array}$ & 1 & 20 & 36 & 12 & 69 & 2.65 & Med \\
\hline 9 & Processing speech at different rates & 0 & 14 & 51 & 8 & 73 & 2.81 & $\mathrm{H}$ \\
\hline 10 & $\begin{array}{l}\text { Processing speech containing pauses, errors, and } \\
\text { corrections }\end{array}$ & 2 & 12 & 39 & 20 & 73 & 2.81 & $\mathrm{H}$ \\
\hline 11 & $\begin{array}{l}\text { Making use of facial, paralinguistic and other clues to } \\
\text { work out meaning }\end{array}$ & 0 & 14 & 51 & 8 & 73 & 2.81 & $\mathrm{H}$ \\
\hline 12 & $\begin{array}{l}\text { Adjusting listening strategies to different kinds of } \\
\text { listener purposes or goals }\end{array}$ & 3 & 14 & 33 & 20 & 70 & 2.69 & Med \\
\hline 13 & $\begin{array}{l}\text { Signaling comprehension or lack of comprehension } \\
\text { verbally and non-verbally }\end{array}$ & 1 & 6 & 48 & 24 & 79 & 3.04 & $\mathrm{H}$ \\
\hline 14 & Identifying purposes and scopes of lecture & 0 & 10 & 48 & 20 & 78 & 3.00 & $\mathrm{H}$ \\
\hline 15 & $\begin{array}{l}\text { Identifying topic of lecture and following topic } \\
\text { development }\end{array}$ & 0 & 8 & 54 & 16 & 78 & 3.00 & $\mathrm{H}$ \\
\hline 16 & $\begin{array}{l}\text { Identifying relationship among units within } \\
\text { discourse (e.g. major ideas, generalizations, } \\
\text { hypotheses, supporting ideas, examples) }\end{array}$ & 2 & 18 & 45 & 0 & 65 & 2.50 & Med \\
\hline 17 & Inferring relationship (e.g. cause, effect, conclusion) & 0 & 14 & 48 & 12 & 74 & 2.85 & $\mathrm{H}$ \\
\hline 18 & Detecting attitude of the speaker toward subject matter & 0 & 6 & 51 & 24 & 81 & 3.12 & $\mathrm{H}$ \\
\hline 19 & $\begin{array}{l}\text { Following different modes of lecturing: spoken, audio, } \\
\text { audio-visual }\end{array}$ & 3 & 14 & 33 & 20 & 70 & 2.69 & Med \\
\hline 20 & Processing faster input & 0 & 12 & 45 & 20 & 77 & 2.96 & $\mathrm{H}$ \\
\hline 21 & Processing lower-frequency vocabulary & 3 & 20 & 33 & 8 & 64 & 2.46 & Med \\
\hline 22 & Processing text with higher vocabulary density & 1 & 18 & 33 & 20 & 72 & 2.77 & Med \\
\hline 23 & Processing more complex structures & 2 & 16 & 45 & 4 & 67 & 2.58 & Med \\
\hline 24 & Processing longer segments & 0 & 14 & 48 & 12 & 74 & 2.85 & $\mathrm{H}$ \\
\hline 25 & Synthesizing scattered information & 0 & 6 & 39 & 40 & 85 & 3.27 & $\mathrm{H}$ \\
\hline 26 & Using word-matching strategies & 1 & 18 & 45 & 4 & 68 & 2.62 & Med \\
\hline 27 & Making text-based inferences & 0 & 6 & 45 & 32 & 83 & 3.19 & $\mathrm{H}$ \\
\hline \multirow[t]{2}{*}{28} & Using background knowledge to make inferences & 1 & 8 & 36 & 36 & 81 & 3.12 & $\mathrm{H}$ \\
\hline & Average Score & & & & & & 2.83 & $\mathrm{H}$ \\
\hline
\end{tabular}

S: Seldom, ST: sometimes, O: Often, VO; Very Often 
considered most difficult are related to Inferring links and connections between events, with a mean score of 3.31 and are in the High $(\mathrm{H})$ category. The second difficult skill/subskill is synthesizing scattered information, with a mean score of 3.27 and is in the High $(\mathrm{H})$ category. Furthermore, other statement statements that also belong to the High $(\mathrm{H})$ category and the average is above the average overall score is:

a) Reconstructing or inferring situations, goals, participant, procedures (score 3.23)

b) Making text-based inferences (score 3.19)

c) Detecting attitude of the speaker toward subject matter (score 3.12)

d) Using background knowledge to make inferences (score 3.12)

e) Signaling comprehension or lack of comprehension verbally and non-verbally (score 3.04)

f) Predicting outcomes from events described (score 3.00)

g) Identifying purposes and scopes of lecture (score 3.00)

h) Identifying topic of lecture and following topic development (score 3.00)

i) Processing faster input (score 2.96)

j) Inferring relationship (e.g. cause, effect, conclusion) (score 2.85) k) Processing longer segments (score of 2.85)

1) Processing speech at different rates (score 2.81)

m) Processing speech containing pauses, errors, and corrections (score 2.81)

n) Making use of facial, paralinguistic and other clues to work out meaning (score 2.81)

1) Text Type

The second aspect of the lack is the issues relating to the type of text being addressed in English. Problems faced by the students regarding this type of texts are revealed using 25 items of statements. The following table illustrates the student's response to the problems they are facing with regard to the type of text.

The table above shows that students are having problems understanding the 10 types of text, with 1 text type being in Very High ( $\mathrm{VH}$ ) category and 9 types of text are in High $(\mathrm{H})$ category. The average overall score is 2.73 or in Medium category (Med). According to students, the type of text related to the news (news) is very difficult for them. This is evidenced by the average score for this type of text is 3.62 or is in the Very High category (VH). Nine (9) text types that are in the High category can be shown in diagram below.

Table 2. Students' problems related to type of texts

\begin{tabular}{|c|c|c|c|c|c|c|c|c|}
\hline No & Genre of texts & $\mathbf{S}$ & ST & $\mathbf{O}$ & VO & Total & Score & Remark \\
\hline 1 & Greeting and Leave taking & 15 & 12 & 15 & 0 & 42 & 1,62 & Low \\
\hline 2 & Personal information & 8 & 26 & 15 & 0 & 49 & 1,88 & Low \\
\hline 3 & Description: person & 6 & 20 & 24 & 8 & 58 & 2.23 & Med \\
\hline 4 & Description: place & 2 & 14 & 30 & 28 & 74 & 2.85 & $\mathrm{H}$ \\
\hline 5 & Procedure: making something & 1 & 18 & 45 & 4 & 68 & 2.62 & Med \\
\hline 6 & Procedure: doing something & 0 & 22 & 33 & 16 & 71 & 2.73 & Med \\
\hline 7 & Exposition & 0 & 4 & 39 & 44 & 87 & 3.35 & $\mathrm{H}$ \\
\hline 8 & Discussion & 2 & 8 & 36 & 32 & 78 & 3.00 & $\mathrm{H}$ \\
\hline 9 & Direction & 0 & 22 & 45 & 0 & 67 & 2.58 & Med \\
\hline 10 & Shopping & 0 & 14 & 36 & 28 & 78 & 3.00 & $\mathrm{H}$ \\
\hline 11 & Narration & 0 & 2 & 42 & 44 & 88 & 3.38 & $\mathrm{H}$ \\
\hline 12 & News & 0 & 2 & 24 & 68 & 94 & 3.62 & VH \\
\hline 13 & Advertisement & 1 & 8 & 33 & 40 & 82 & 3.15 & $\mathrm{H}$ \\
\hline 14 & Announcement & 4 & 16 & 33 & 12 & 65 & 2.50 & Med \\
\hline 15 & Biography & 5 & 16 & 30 & 12 & 63 & 2.42 & Med \\
\hline 16 & Life cycle & 0 & 14 & 33 & 32 & 79 & 3.04 & $\mathrm{H}$ \\
\hline 17 & Giving opinion & 4 & 14 & 27 & 24 & 69 & 2.65 & Med \\
\hline 18 & Suggestion & 2 & 12 & 36 & 24 & 74 & 2.85 & $\mathrm{H}$ \\
\hline 19 & Telephone call & 4 & 16 & 36 & 8 & 64 & 2.46 & Med \\
\hline 20 & Invitation & 3 & 14 & 27 & 28 & 72 & 2.77 & Med \\
\hline 21 & Apology & 2 & 18 & 33 & 16 & 69 & 2.65 & Med \\
\hline 22 & Request & 7 & 20 & 15 & 16 & 58 & 2.23 & Med \\
\hline 23 & Prediction & 0 & 4 & 48 & 32 & 84 & 3.23 & Med \\
\hline 24 & Lecture & 2 & 10 & 30 & 36 & 78 & 3.00 & $\mathrm{H}$ \\
\hline \multirow[t]{2}{*}{25} & Job application & 5 & 18 & 24 & 16 & 63 & 2.42 & Med \\
\hline & Average Score & & & & & & 2.73 & Med \\
\hline
\end{tabular}

S: Seldom, ST: sometimes, O: Often, VO; Very Often 


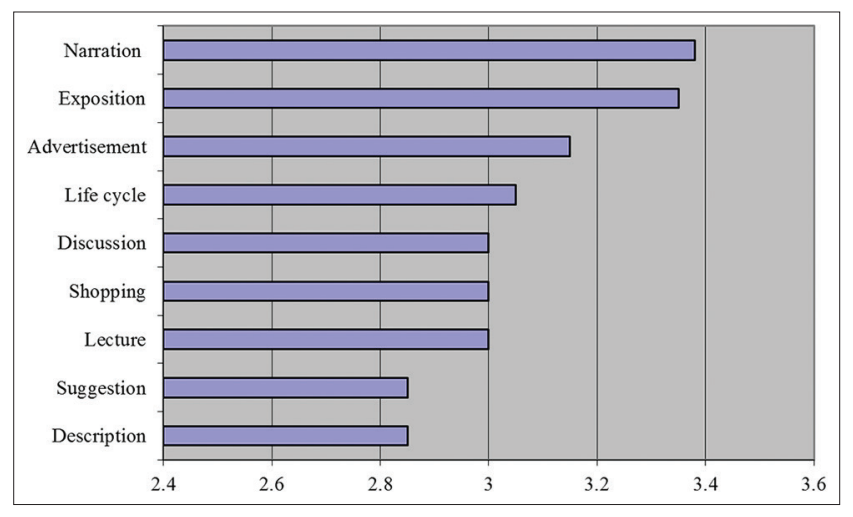

Diagram 1. Students' the highest problems on the type of text
2) Task Type/Activity

The third aspect is the type of task/exercise. Student issues related to the type of task/exercise are expressed using 25 statements. The following table illustrates the score of respondents to each item statement.

The results of the analysis presented in the table above show that there are 10 statements that are in the High $(\mathrm{H})$ category. No statements are in the Very High category $(\mathrm{VH})$, there are 14 statements that are in Medium category (Med), and 1 statement is in Low category (Low). The overall average score is 2.71 and is in the Medium category (Med). According to the students, the types of tasks with problem levels that are above the average overall score are:

Table 3. Students' problems related to task/activity

\begin{tabular}{|c|c|c|c|c|c|c|c|c|}
\hline No & Task Types & $\mathbf{S}$ & ST & $\mathbf{O}$ & Vo & Total & Score & remark \\
\hline 1 & Listeners are told to draw a certain object & 4 & 20 & 36 & 0 & 60 & 2.31 & Med \\
\hline 2 & $\begin{array}{l}\text { Listeners listen two utterances and indicate whether there } \\
\text { were the same of different }\end{array}$ & 4 & 16 & 30 & 16 & 66 & 2.54 & Med \\
\hline 3 & Listeners listen to an utterance and write it down & 2 & 16 & 36 & 16 & 70 & 2.69 & Med \\
\hline 4 & $\begin{array}{l}\text { Listeners listen to a statement, and then look at a number } \\
\text { of pictures and indicate which represent the statement }\end{array}$ & 2 & 18 & 36 & 12 & 68 & 2.62 & Med \\
\hline 5 & $\begin{array}{l}\text { Listeners look at a picture and listen to a number of } \\
\text { statements, and then choose which is relevant to the } \\
\text { picture }\end{array}$ & 4 & 14 & 33 & 16 & 67 & 2.58 & Med \\
\hline 6 & $\begin{array}{l}\text { Listeners are shown a complex picture with many things } \\
\text { happening in it, they hear a series of statements about the } \\
\text { picture and indicate whether these are true or false }\end{array}$ & 3 & 16 & 30 & 20 & 69 & 2.65 & Med \\
\hline 7 & $\begin{array}{l}\text { Listeners look at four pictures labeled A, B, C and D, and } \\
\text { listen to a series of utterances, and indicate which picture } \\
\text { each utterance applies to }\end{array}$ & 2 & 16 & 42 & 8 & 68 & 2.62 & Med \\
\hline 8 & $\begin{array}{l}\text { Listeners see a series of simple diagrams, listen to } \\
\text { statements describing these, and indicate which diagram is } \\
\text { being described }\end{array}$ & 2 & 12 & 30 & 32 & 76 & 2.92 & $\mathrm{H}$ \\
\hline 9 & $\begin{array}{l}\text { Listeners listen to a statement followed by a response, and } \\
\text { indicate } \mathrm{A} \text { if the response was appropriate, and B if it was } \\
\text { not }\end{array}$ & 4 & 14 & 45 & 0 & 63 & 2.42 & Med \\
\hline 10 & $\begin{array}{l}\text { Listeners listen to a question followed by three possible } \\
\text { responses, and indicate which was the most appropriate }\end{array}$ & 4 & 14 & 39 & 8 & 65 & 2.50 & Med \\
\hline 11 & $\begin{array}{l}\text { Listeners listen to a statement followed by three possible } \\
\text { continuations, and select one that would continue the } \\
\text { conversation best }\end{array}$ & 2 & 8 & 36 & 32 & 78 & 3.00 & $\mathrm{H}$ \\
\hline 12 & $\begin{array}{l}\text { Listeners listen to a short conversation, and then listen to } \\
\text { a short question about it, to which they choose one of four } \\
\text { options }\end{array}$ & 3 & 12 & 36 & 20 & 71 & 2.73 & Med \\
\hline 13 & $\begin{array}{l}\text { Listeners listen to recordings from the radio, and indicate } \\
\text { what type of program they are listening to (e.g. news, } \\
\text { sport, weather, fashion, etc.) }\end{array}$ & 3 & 10 & 33 & 28 & 74 & 2.85 & $\mathrm{H}$ \\
\hline 14 & $\begin{array}{l}\text { Listeners listen to a description of a person, place or thing } \\
\text { they are all familiar with, and write down its name, or } \\
\text { what it is }\end{array}$ & 7 & 20 & 21 & 8 & 56 & 2.15 & Low \\
\hline 15 & $\begin{array}{l}\text { Listeners listen to a dialogue, and then answer a } \\
\text { number of multiple-choice questions. }\end{array}$ & 3 & 18 & 33 & 12 & 66 & 2.54 & Med \\
\hline
\end{tabular}


Table 3. (Continued)

\begin{tabular}{|c|c|c|c|c|c|c|c|c|}
\hline No & Task Types & $\mathbf{S}$ & ST & $\mathbf{O}$ & Vo & Total & Score & remark \\
\hline 16 & $\begin{array}{l}\text { Listeners listen to a monologue, and then answer a number } \\
\text { of multiple-choice questions. }\end{array}$ & 2 & 18 & 36 & 12 & 68 & 2.62 & Med \\
\hline 17 & $\begin{array}{l}\text { Listeners listen to a monologue or dialogue, and then } \\
\text { answer a number of short-answer comprehension } \\
\text { questions on it. }\end{array}$ & 1 & 14 & 36 & 24 & 75 & 2.88 & $\mathrm{H}$ \\
\hline 18 & $\begin{array}{l}\text { Listeners listen to a short talk or lecture, read a number of } \\
\text { statements and select a correct one. }\end{array}$ & 1 & 6 & 39 & 36 & 82 & 3.15 & $\mathrm{H}$ \\
\hline 19 & $\begin{array}{l}\text { Listeners listen to a short talk or lecture and answer } \\
\text { comprehension questions about it. }\end{array}$ & 0 & 10 & 45 & 24 & 79 & 3.04 & $\mathrm{H}$ \\
\hline 20 & $\begin{array}{l}\text { Listeners are given a map and a starting point, follow } \\
\text { directions on the map, and then indicate the destination. }\end{array}$ & 2 & 10 & 30 & 36 & 78 & 3.00 & $\mathrm{H}$ \\
\hline 21 & $\begin{array}{l}\text { Listeners listen to an announcement of some information } \\
\text { and fill in the information in a grid }\end{array}$ & 3 & 10 & 36 & 24 & 73 & 2.81 & $\mathrm{H}$ \\
\hline 22 & $\begin{array}{l}\text { Listeners are given a goal, they listen to an announcement } \\
\text { or explanation, find the information necessary to complete } \\
\text { their goal, and then do the task }\end{array}$ & 2 & 10 & 36 & 28 & 76 & 2.92 & $\mathrm{H}$ \\
\hline 23 & $\begin{array}{l}\text { Listeners listen to a person on the telephone and take a } \\
\text { message according to the speaker's instructions. }\end{array}$ & 3 & 16 & 39 & 8 & 66 & 2.54 & Med \\
\hline 24 & $\begin{array}{l}\text { Listeners look at a picture and draw in objects or other } \\
\text { details according to instructions }\end{array}$ & 3 & 14 & 30 & 24 & 71 & 2.73 & Med \\
\hline \multirow[t]{2}{*}{25} & $\begin{array}{l}\text { Listeners see a series of pictures and listen to a talk or } \\
\text { discussion and then classify the picture based on the talk. }\end{array}$ & 2 & 10 & 33 & 32 & 77 & 2.96 & $\mathrm{H}$ \\
\hline & Average Score & & & & & & 2.71 & Med \\
\hline
\end{tabular}

S: Seldom, ST: sometimes, O: Often, VO; Very Often

1) Listeners listen to a short talk or lecture, read a number of statements and select a correct one. (score 3.15)

2) Listeners listen to a short talk or lecture and answer comprehension questions about it. (score 3.04)

3) Listeners listen to a statement followed by three possible continuations, and select one that would continue the conversation best (score 3.00)

4) Listeners are given a map and a starting point, follow directions on the map, and then indicate the destination. (score 3.00)

5) Listeners see a series of pictures and listen to a talk or discussion and then classify the picture based on the talk. (score 2.96)

6) Listeners see a series of simple diagrams, listen to statements describing these, and indicate which diagram is being described (score 2.92)

7) Listeners are given a goal, they listen to an announcement or explanation, find the information necessary to complete their goal, and then do the task (score 2.92)

8) Listeners listen to a monologue or dialogue, and then answer a number of short-answer comprehension questions on it. (score 2.88)

9) Listeners listen to recordings from the radio, and indicate what type of program they are listening to (e.g. news, sport, weather, fashion, etc.) (score 2.85)

10) Listeners listen to an announcement of some information and fill in the information in a grid (score 2.81)

11) Listeners look at a picture and draw in objects or other details according to instructions (score 2.73).

\section{Want}

The third aspect in needs analysis is desire. Information regarding this aspect is extracted from two sources, ie information from students. Here is the result of the analysis of the data obtained from the students. Information needs of students obtained through the distribution of questionnaires information needs to students. Questionnaires that have been designed and validated are distributed to the students to find out some information such as: 1) identifying skills and sub-listening skills that are considered important, 2) identify the types of texts (genres) considered important, 3) identify the types of exercises considered important 4) listening sources considered important, and 5) media types considered important.

Questionnaires were distributed to 26 students selected by cluster random sampling. Questionnaire uses 4 answer choices, namely Unimportant (UI), Less Important (LI), Important (I), and Very Important (VI). The following descriptions of needs based on the results of the distribution of questionnaires to students.

\section{Skills and sub-skills that are considered important}

Students' needs related to the skills and sub-skill of listening that are considered important are expressed using 28 point statement. The following table illustrates the score of student responses to each of the statements.

The table above shows that all listening skills/sub-skills are very important or important for the student, with the de- 
Table 4. Score of respondents' response on skills and sub-skill needed

\begin{tabular}{|c|c|c|c|c|c|c|c|c|}
\hline No & Listening Skill/Sub-skills & UI & LI & $\mathbf{I}$ & VI & Total & Score & Remark \\
\hline 1 & $\begin{array}{l}\text { Detecting meanings expressed in differing grammatical } \\
\text { forms/sentence types }\end{array}$ & 0 & 2 & 54 & 28 & 84 & 3.23 & $\mathrm{~T}$ \\
\hline 2 & $\begin{array}{l}\text { Recognizing the communicative function of utterances, } \\
\text { according to situation, participants, goals }\end{array}$ & 0 & 4 & 45 & 36 & 85 & 3.27 & $\mathrm{~T}$ \\
\hline 3 & $\begin{array}{l}\text { Reconstructing or inferring situations, goals, } \\
\text { participant, procedures }\end{array}$ & 0 & 4 & 54 & 24 & 82 & 3.15 & $\mathrm{~T}$ \\
\hline 4 & $\begin{array}{l}\text { Using real-world knowledge and experience to work } \\
\text { out purpose, goal, setting, and procedure }\end{array}$ & 2 & 0 & 30 & 56 & 88 & 3.38 & $\mathrm{~T}$ \\
\hline 5 & Predicting outcomes from events described & 0 & 10 & 42 & 28 & 80 & 3.08 & $\mathrm{~T}$ \\
\hline 6 & Inferring links and connections between events & 0 & 10 & 42 & 28 & 80 & 3.08 & $\mathrm{~T}$ \\
\hline 7 & Distinguishing between literal and applied meanings & 0 & 8 & 48 & 24 & 80 & 3.08 & $\mathrm{~T}$ \\
\hline 8 & $\begin{array}{l}\text { Recognizing coherence in discourse, and detecting } \\
\text { such relations as main idea, supporting idea, given } \\
\text { information, new information, generalization, } \\
\text { exemplification }\end{array}$ & 0 & 6 & 39 & 40 & 85 & 3.27 & $\mathrm{~T}$ \\
\hline 9 & Processing speech at different rates & 0 & 4 & 51 & 28 & 83 & 3.19 & $\mathrm{~T}$ \\
\hline 10 & $\begin{array}{l}\text { Processing speech containing pauses, errors, and } \\
\text { corrections }\end{array}$ & 0 & 10 & 45 & 24 & 79 & 3.04 & $\mathrm{~T}$ \\
\hline 11 & $\begin{array}{l}\text { Making use of facial, paralinguistic and other clues to } \\
\text { work out meaning }\end{array}$ & 0 & 4 & 51 & 28 & 83 & 3.19 & $\mathrm{~T}$ \\
\hline 12 & $\begin{array}{l}\text { Adjusting listening strategies to different kinds of } \\
\text { listener purposes or goals }\end{array}$ & 0 & 2 & 42 & 44 & 88 & 3.38 & $\mathrm{~T}$ \\
\hline 13 & $\begin{array}{l}\text { Signaling comprehension or lack of comprehension } \\
\text { verbally and non-verbally }\end{array}$ & 1 & 12 & 48 & 12 & 73 & 2.81 & $\mathrm{~T}$ \\
\hline 14 & Identifying purposes and scopes of lecture & 0 & 10 & 48 & 20 & 78 & 3.00 & $\mathrm{~T}$ \\
\hline 15 & $\begin{array}{l}\text { Identifying topic of lecture and following topic } \\
\text { development }\end{array}$ & 0 & 8 & 54 & 16 & 78 & 3.00 & $\mathrm{~T}$ \\
\hline 16 & $\begin{array}{l}\text { Identifying relationship among units within } \\
\text { discourse (e.g. major ideas, generalizations, } \\
\text { hypotheses, supporting ideas, examples) }\end{array}$ & 0 & 0 & 51 & 36 & 87 & 3.35 & $\mathrm{~T}$ \\
\hline 17 & Inferring relationship (e.g. cause, effect, conclusion) & 0 & 6 & 48 & 28 & 82 & 3.15 & $\mathrm{~T}$ \\
\hline 18 & Detecting attitude of the speaker toward subject matter & 0 & 12 & 45 & 20 & 77 & 2.96 & $\mathrm{~T}$ \\
\hline 19 & $\begin{array}{l}\text { Following different modes of lecturing: spoken, audio, } \\
\text { audio-visual }\end{array}$ & 0 & 2 & 39 & 48 & 89 & 3.42 & ST \\
\hline 20 & Processing faster input & 0 & 10 & 45 & 24 & 79 & 3.04 & $\mathrm{~T}$ \\
\hline 21 & Processing lower-frequency vocabulary & 0 & 4 & 42 & 40 & 86 & 3.31 & $\mathrm{~T}$ \\
\hline 22 & Processing text with higher vocabulary density & 0 & 12 & 33 & 36 & 81 & 3.12 & $\mathrm{~T}$ \\
\hline 23 & Processing more complex structures & 0 & 2 & 51 & 32 & 85 & 3.27 & $\mathrm{~T}$ \\
\hline 24 & Processing longer segments & 0 & 6 & 48 & 28 & 82 & 3.15 & $\mathrm{~T}$ \\
\hline 25 & Synthesizing scattered information & 0 & 8 & 45 & 28 & 81 & 3.12 & $\mathrm{~T}$ \\
\hline 26 & Using word-matching strategies & 0 & 2 & 48 & 36 & 86 & 3.31 & $\mathrm{~T}$ \\
\hline 27 & Making text-based inferences & 0 & 8 & 45 & 28 & 81 & 3.12 & $\mathrm{~T}$ \\
\hline \multirow[t]{2}{*}{28} & Using background knowledge to make inferences & 0 & 8 & 36 & 40 & 84 & 3.23 & $\mathrm{~T}$ \\
\hline & Average Score & & & & & & 3.17 & $\mathrm{~T}$ \\
\hline
\end{tabular}

tails of 1 statement being in Very High $(\mathrm{VH})$ category and 27 statements are in High $(\mathrm{H})$ category. The overall average score is 3.17 and is in the High $(\mathrm{H})$ category. According to the students, listening skills related to listening to lecturers' explanations, both audio and visual (following different modes of lecturing: spoken, audio, audio-visual) are very important to them. This is evidenced by the highest average score in this statement (average score 3.42). Skills with regard to signaling comprehension or lack of comprehension verbally and non-verbally scored lowest, with a mean score of 2.81 .

Furthermore, there are 27 statements that get the average score with the category High $(\mathrm{H})$. Some statement state- 
Table 5. Score of text type based on respondents' response

\begin{tabular}{|c|c|c|c|c|c|c|c|c|}
\hline No & Text Types (Genre) & UI & LI & I & VI & Total & Score & Remark \\
\hline 1 & Greeting and Leave taking & 0 & 10 & 45 & 24 & 79 & 3.04 & $\mathrm{H}$ \\
\hline 2 & Personal information & 0 & 10 & 39 & 32 & 81 & 3.12 & $\mathrm{H}$ \\
\hline 3 & Description: person & 1 & 4 & 45 & 32 & 82 & 3.15 & $\mathrm{H}$ \\
\hline 4 & Description: place & 0 & 0 & 54 & 32 & 86 & 3.31 & $\mathrm{H}$ \\
\hline 5 & Procedure: making something & 0 & 2 & 45 & 40 & 87 & 3.35 & $\mathrm{H}$ \\
\hline 6 & Procedure: doing something & 0 & 4 & 39 & 44 & 87 & 3.35 & $\mathrm{H}$ \\
\hline 7 & Exposition & 0 & 4 & 39 & 44 & 87 & 3.35 & $\mathrm{H}$ \\
\hline 8 & Discussion & 0 & 0 & 42 & 48 & 90 & 3.46 & VH \\
\hline 9 & Direction & 0 & 0 & 45 & 44 & 89 & 3.42 & VH \\
\hline 10 & Shopping & 0 & 14 & 36 & 28 & 78 & 3.00 & $\mathrm{H}$ \\
\hline 11 & Narration & 0 & 2 & 42 & 44 & 88 & 3.38 & $\mathrm{H}$ \\
\hline 12 & News & 0 & 2 & 24 & 68 & 94 & 3.62 & VH \\
\hline 13 & Advertisement & 0 & 4 & 42 & 40 & 86 & 3.31 & $\mathrm{H}$ \\
\hline 14 & Announcement & 0 & 4 & 33 & 52 & 89 & 3.42 & $\mathrm{VH}$ \\
\hline 15 & Biography & 0 & 10 & 45 & 24 & 79 & 3.04 & $\mathrm{H}$ \\
\hline 16 & Life cycle & 0 & 14 & 33 & 32 & 79 & 3.04 & $\mathrm{H}$ \\
\hline 17 & Giving opinion & 0 & 14 & 27 & 40 & 81 & 3.12 & $\mathrm{H}$ \\
\hline 18 & Suggestion & 0 & 6 & 36 & 44 & 86 & 3.31 & $\mathrm{H}$ \\
\hline 19 & Telephone call & 0 & 8 & 36 & 40 & 84 & 3.23 & $\mathrm{H}$ \\
\hline 20 & Invitation & 0 & 10 & 36 & 36 & 82 & 3.15 & $\mathrm{H}$ \\
\hline 21 & Apology & 0 & 8 & 33 & 44 & 85 & 3.27 & $\mathrm{H}$ \\
\hline 22 & Request & 0 & 6 & 36 & 44 & 86 & 3.31 & $\mathrm{H}$ \\
\hline 23 & Prediction & 0 & 4 & 48 & 32 & 84 & 3.23 & $\mathrm{H}$ \\
\hline 24 & Lecture & 0 & 6 & 42 & 36 & 84 & 3.23 & $\mathrm{H}$ \\
\hline \multirow[t]{2}{*}{25} & Job application & 0 & 2 & 24 & 68 & 94 & 3.62 & VH \\
\hline & Average Score & & & & & & 3.27 & \\
\hline
\end{tabular}

ments that fall into this category and the average is above the average overall score is:

1) Using real-world knowledge and experience to work out purpose, goal, setting, and procedure (score 3.38)

2) Adjusting listening strategies to different kinds of listener purposes or goals (score 3.38)

3) Identifying relationship among units within discourse (e.g. major ideas, generalizations, hypotheses, supporting ideas, examples) (score 3.35)

4) Processing lower-frequency vocabulary (score 3.31)

5) Using word-matching strategies (score 3.31)

6) Recognizing the communicative function of utterances, according to situation, participants, goals (score 3.27)

7) Recognizing coherence in discourse, and detecting such relations as main idea, supporting idea, given information, new information, generalization, exemplification (score 3.27)

8) Processing more complex structures (score 3.27)

9) Detecting meanings expressed in differing grammatical forms/sentence types (score 3.23)

10) Using background knowledge to make inferences (score 3.23)

11) Processing speech at different rates (score 3.19)
12) Making use of facial, paralinguistic and other clues to work out meaning (score 3.19).

\section{The type of genre considered important}

The students' wishes regarding the type of text were expressed using 25 point statements. The following table illustrates the score of respondents to each item:

The table above shows that all items of statements pertaining to the type of text are very important or important to the student, with the details of the 5 statements being in the Very High (VH) category and 20 statements in the High $(\mathrm{H})$ category. The average overall score is 3.27 and is in the High $(\mathrm{H})$ category. According to students, the type of text related to the news (news) is very important for them. This is evidenced by the average score for this type of text is 3.62 and job application text (job application) with average score 3.62. Three (3) other text types that are also in the Very High category ( $\mathrm{VH}$ ) are the text in the form of discussion with the average score of 3.46 , the text is in the direction with the average score of 3.42, and the text related to announcement (announcement) with average score 3.42 . This is very natural, because the average 
Table 6. Score of respondents responses on exercise/task

\begin{tabular}{|c|c|c|c|c|c|c|c|c|}
\hline No & Task Types & UI & $\mathbf{L I}$ & $\mathbf{I}$ & VI & Total & Score & Remark \\
\hline 1 & Listeners are told to draw a certain object & 0 & 8 & 54 & 16 & 78 & 3.00 & $\mathrm{H}$ \\
\hline 2 & $\begin{array}{l}\text { Listeners listen two utterances and indicate whether there } \\
\text { were the same of different }\end{array}$ & 0 & 8 & 42 & 32 & 82 & 3.15 & $\mathrm{H}$ \\
\hline 3 & Listeners listen to an utterance and write it down & 0 & 6 & 39 & 40 & 85 & 3.27 & $\mathrm{H}$ \\
\hline 4 & $\begin{array}{l}\text { Listeners listen to a statement, and then look at a number } \\
\text { of pictures and indicate which represent the statement }\end{array}$ & 0 & 6 & 42 & 36 & 84 & 3.23 & $\mathrm{H}$ \\
\hline 5 & $\begin{array}{l}\text { Listeners look at a picture and listen to a number of } \\
\text { statements, and then choose which is relevant to the picture }\end{array}$ & 0 & 10 & 39 & 32 & 81 & 3.12 & $\mathrm{H}$ \\
\hline 6 & $\begin{array}{l}\text { Listeners are shown a complex picture with many things } \\
\text { happening in it, they hear a series of statements about the } \\
\text { picture and indicate whether these are true or false }\end{array}$ & 0 & 10 & 39 & 32 & 81 & 3.12 & $\mathrm{H}$ \\
\hline 7 & $\begin{array}{l}\text { Listeners look at four pictures labeled A, B, C and D, and } \\
\text { listen to a series of utterances, and indicate which picture } \\
\text { each utterance applies to }\end{array}$ & 0 & 4 & 42 & 40 & 86 & 3.31 & $\mathrm{H}$ \\
\hline 8 & $\begin{array}{l}\text { Listeners see a series of simple diagrams, listen to } \\
\text { statements describing these, and indicate which diagram is } \\
\text { being described }\end{array}$ & 0 & 4 & 48 & 32 & 84 & 3.23 & $\mathrm{H}$ \\
\hline 9 & $\begin{array}{l}\text { Listeners listen to a statement followed by a response, and } \\
\text { indicate } \mathrm{A} \text { if the response was appropriate, and B if not }\end{array}$ & 0 & 8 & 45 & 28 & 81 & 3.12 & $\mathrm{H}$ \\
\hline 10 & $\begin{array}{l}\text { Listeners listen to a question followed by three possible } \\
\text { responses, and indicate which was the most appropriate }\end{array}$ & 0 & 8 & 45 & 28 & 81 & 3.12 & $\mathrm{H}$ \\
\hline 11 & $\begin{array}{l}\text { Listeners listen to a statement followed by three possible } \\
\text { continuations, and select one that would continue the } \\
\text { conversation best }\end{array}$ & 0 & 8 & 42 & 32 & 82 & 3.15 & $\mathrm{H}$ \\
\hline 12 & $\begin{array}{l}\text { Listeners listen to a short conversation, and then listen to } \\
\text { a short question about it, to which they choose one of four } \\
\text { options }\end{array}$ & 0 & 4 & 36 & 48 & 88 & 3.38 & $\mathrm{H}$ \\
\hline 13 & $\begin{array}{l}\text { Listeners listen to recordings from the radio, and indicate } \\
\text { what type of program they are listening to (e.g. news, } \\
\text { sport, weather, fashion, etc.) }\end{array}$ & 0 & 6 & 33 & 48 & 87 & 3.35 & $\mathrm{H}$ \\
\hline 14 & $\begin{array}{l}\text { Listeners listen to a description of a person, place or thing } \\
\text { they are all familiar with, and write down its name, etc }\end{array}$ & 0 & 2 & 45 & 40 & 87 & 3.35 & $\mathrm{H}$ \\
\hline 15 & $\begin{array}{l}\text { Listeners listen to a dialogue, and then answer a number } \\
\text { of multiple-choice questions. }\end{array}$ & 0 & 6 & 42 & 36 & 84 & 3.23 & $\mathrm{H}$ \\
\hline 16 & $\begin{array}{l}\text { Listeners listen to a monologue, and then answer a number } \\
\text { of multiple-choice questions. }\end{array}$ & 0 & 10 & 36 & 36 & 82 & 3.15 & $\mathrm{H}$ \\
\hline 17 & $\begin{array}{l}\text { Listeners listen to a monologue or dialogue, and then answer } \\
\text { a number of short-answer comprehension questions on it. }\end{array}$ & 1 & 2 & 45 & 36 & 84 & 3.23 & $\mathrm{H}$ \\
\hline 18 & $\begin{array}{l}\text { Listeners listen to a short talk or lecture, read a number of } \\
\text { statements and select a correct one. }\end{array}$ & 1 & 6 & 39 & 36 & 82 & 3.15 & $\mathrm{H}$ \\
\hline 19 & $\begin{array}{l}\text { Listeners listen to a short talk or lecture and answer } \\
\text { comprehension questions about it. }\end{array}$ & 0 & 10 & 45 & 24 & 79 & 3.04 & $\mathrm{H}$ \\
\hline 20 & $\begin{array}{l}\text { Listeners are given a map and a starting point, follow } \\
\text { directions on the map, and then indicate the destination. }\end{array}$ & 0 & 10 & 36 & 36 & 82 & 3.15 & $\mathrm{H}$ \\
\hline 21 & $\begin{array}{l}\text { Listeners listen to an announcement of some information } \\
\text { and fill in the information in a grid }\end{array}$ & 0 & 8 & 51 & 20 & 79 & 3.04 & $\mathrm{H}$ \\
\hline 22 & $\begin{array}{l}\text { Listeners are given a goal, they listen to an announcement } \\
\text { or explanation, find the information necessary to complete } \\
\text { their goal, and then do the task }\end{array}$ & 0 & 6 & 48 & 28 & 82 & 3.15 & $\mathrm{H}$ \\
\hline 23 & $\begin{array}{l}\text { Listeners listen to a person on the telephone and take a } \\
\text { message according to the speaker's instructions. }\end{array}$ & 0 & 2 & 48 & 36 & 86 & 3.31 & $\mathrm{H}$ \\
\hline 24 & $\begin{array}{l}\text { Listeners look at a picture and draw in objects or other } \\
\text { details according to instructions }\end{array}$ & 0 & 14 & 36 & 28 & 78 & 3.00 & $\mathrm{H}$ \\
\hline \multirow[t]{2}{*}{25} & $\begin{array}{l}\text { Listeners see a series of pictures and listen to a talk or } \\
\text { discussion and then classify the picture based on the talk. }\end{array}$ & 0 & 6 & 45 & 32 & 83 & 3.19 & $\mathrm{H}$ \\
\hline & Average Score & & & & & & 3.18 & $\mathrm{H}$ \\
\hline
\end{tabular}


student has problems with the development of these types of texts.

Furthermore, there are 20 statements that get the average score with the category High $(\mathrm{H})$. Types of texts with mean scores above the overall mean (3.27) are narrative texts (score averages 3.38), the text of the procedure of making something (score average 3.35), the text of the procedure of doing something (score 3.35), expository text (score average 3.35), place description text (score average 3.31), text related to advertisement (score average 3.31), suggestion text (score average 3.31), demand-related text (score of 3.31) and apology-related text (average score 3.27). This findings are relevant with the recommendation of Sadeghi, Hassan, \& Noory (2014) that genre-based listening learning needs to be emphasized in order for students to understand the various texts.

\section{Type of exercise/task}

The third aspect is the type of task/exercise. The students' wishes regarding the types of tasks/exercises are expressed using 25 point statements. The following table illustrates the score of respondents to each item.

The results of the analysis presented in the table above show that all the components present in the type of task/exercise are important for the student, with the details of all statements being in the High $(\mathrm{H})$ category. No statements are in Very High (VH), Medium (Med), Low (Low) and Very Low (VL) categories. The average overall score is 3.18 and is in the High $(\mathrm{H})$ category. According to the students, the types of tasks with a level of importance that are above the average overall score are:

1) Listeners listen to a short conversation, and then listen to a short question about it, to which they choose one of four options (score 3.38)

2) Listeners listen to recordings from the radio, and indicate what type of program they are listening to (e.g. news, sport, weather, fashion, etc.) (score 3.35)

3) Listeners listen to a description of a person, place or thing they are all familiar with, and write down its name, or what it is (score 3.35)

4) Listeners look at four pictures labeled A, B, C and D, and listen to a series of utterances, and indicate which picture each utterance applies to (score 3.31)
5) Listeners listen to a person on the telephone and take a message according to the speaker's instructions (score 3.31)

6) Listeners listen to an utterance and write it down (score 3.27)

7) Listeners listen to a statement, and then look at a number of pictures and indicate which represent the statement (score 3.23)

8) Listeners see a series of simple diagrams, listen to statements describing these, and indicate which diagram is being described (score 3.23)

9) Listeners listen to a dialogue, and then answer a number of multiple-choice questions (score 3.23)

10) Listeners listen to a monologue or dialogue, and then answer a number of short-answer comprehension questions on it (score 3.23)

11) Listeners see a series of pictures and listen to a talk or discussion and then classify the picture based on the talk (score 3.19).

\section{Source of Listening Materials}

The fourth aspect is the listening resources. The students' wishes with regard to listening sources are expressed using 9 items of statements. The following table illustrates the score of respondents to each item.

The results of the analysis presented in the table above show that all the components related to the listening sources are very important or important for the student, with the details of the 5 statements being in the Very High $(\mathrm{VH})$ category and 4 items in the High $(\mathrm{H})$ category. No statements are in Medium (Med), Low (Low) and Very Low (VL) categories. The overall average score is 3.37 and is in the High $(\mathrm{H})$ category. According to the students, 5 types of listening sources that are very important to them are (a) film clips (score 3.58), (b) listening material (audio/video) from course books (score 3.54 ), (c) live recording (score of 3.50), (d) audio CD recording materials (score 3.42), and (e) VCD/DVD recording materials (score 3.42). These five listening sources need a deeper proportion of opinion in developing teaching material.

This condition shows that students really need multimedia materials. To minimize the gap between student needs

Table 7. Score of respondents' response on source of listening materials

\begin{tabular}{llcccccccc}
\hline No & Item & UI & LI & I & VI & Total & Score & Remark \\
\hline 1 & Film Clips & 0 & 0 & 33 & 60 & 93 & 3.58 & VH \\
2 & Television Programs & 0 & 6 & 36 & 44 & 86 & 3.31 & $\mathrm{H}$ \\
3 & Audio/CD Recording Materials & 1 & 0 & 36 & 52 & 89 & 3.42 & $\mathrm{VH}$ \\
4 & VCD/DVD Recording Materials & 0 & 4 & 33 & 52 & 89 & 3.42 & $\mathrm{VH}$ \\
5 & Listening Materials from Internet & 0 & 8 & 27 & 52 & 87 & 3.35 & $\mathrm{H}$ \\
6 & Documentary Clips & 1 & 12 & 33 & 32 & 78 & 3.00 & $\mathrm{H}$ \\
7 & Radio Broadcasting Materials & 1 & 6 & 33 & 44 & 84 & 3.23 & $\mathrm{H}$ \\
8 & Live recording & 0 & 0 & 39 & 52 & 91 & 3.50 & $\mathrm{VH}$ \\
9 & Listening materials (Audio/Video) from course & 0 & 4 & 24 & 64 & 92 & 3.54 & $\mathrm{VH}$ \\
& books & & & & & & & & \\
& Average Score & & & & & & & 3.37 \\
\hline
\end{tabular}


and objective conditions in the field, a new syllabus should be developed based on the results of theoretical studies in line with the results of needs analysis. A suitable syllabus is a mixed syllabus combining some of the best elements of a structural, structural syllabus, a syllabus based on the topic, theme, and text-based syllabus. This finding also supports Al-Hammadi finding about the effect of multimedia in listening class (Al-Hammadi, 2011).

\section{Type of media}

The fifth aspect is the types of media used. The students' wishes regarding the types of media used in the listening lesson were revealed using 10 items of statement. The following table illustrates the score of respondents to each item.

The results of the analysis presented in the table above show that all the components related to the types of media used for listening learning are very important or important for the student, with the details of the 2 items of statement being in the Very High category $(\mathrm{VH})$ and 8 items statement in the category High $(\mathrm{H})$. No statements are in Medium (Med), Low (Low) and Very Low (VL) categories. The average score overall is 3.23 and is in the High $(\mathrm{H})$ category. According to students, 2 types of media that are very important for them are (a) Video recording for classroom study (score 3.50) and (b) Audio Recording for classroom study (score 3.46). While the types of media above the overall average score are (a) Video recording for self-study (score 3.38) and (b) Audio Recording for self-study (score 3.31). These four types of media desperately need an opinion of more proportion in developing teaching material to listen. This finding is in line with Woottipong that the use of video material on learning listening skills in college shows is really necessary. It is because these materials give significant improvements in student listening skills between before the experiment and after the experiment, and students have a positive attitude towards the use of video in learning listening (Woottipong, 2014).
Based on comparison between the results of the needs analysis and the result of the situation analysis, it shows that there is a gap between the wishes of the students and the lecturers of listening subjects with the objective facts found in the field with regard to teaching material in English. This gap is seen in (a) the types of information needed, (b) the types of texts being taught, (c) the types of themes discussed, and (d) the types of tasks undertaken by students. In other words, the syllabus and teaching materials that existed before the study were conducted could not meet the students' need for listening material in accordance with their wishes, institutional goals, and the wishes of the graduate users. The objective condition is also in line with the findings of Asma (2013) that lack of implementation of multimedia in listening has an effect student motivation and negative attitude of students to this listening skill.

To minimize the gap between student needs and conditions in the field, a new syllabus and multimedia and genrebased materials should be developed based on the results of theoretical studies and the results of these needs analysis. The needs of genre-based material are based on students' needs. It is in line with Sadeghi, Hassan, and Noory (2014) that genre-based listening inputs have a positive impact on listening skills of Iranian students who learn English as a foreign language.

\section{CONCLUSION}

Based on this research, it can be concluded that the comparison between the results of the needs analysis and the result of the situation analysis shows that there is a gap between the wishes of the students and the lecturers of listening subjects with the objective facts found in the field with regard to teaching material in English. This gap is seen in (a) the types of information needed, (b) the types of texts being taught, (c) the types of themes discussed, and (d) the types of tasks undertaken by students. In other words, the syllabus and teach-

Table 8. Score of respondents' response on type of media

\begin{tabular}{|c|c|c|c|c|c|c|c|c|}
\hline No & Item & UI & LI & I & VI & Total & Score & Remark \\
\hline 1 & Audio Recording for classroom study & 0 & 0 & 42 & 48 & 90 & 3.46 & $\mathrm{VH}$ \\
\hline 2 & Audio Recording for self-study & 1 & 2 & 39 & 44 & 86 & 3.31 & $\mathrm{H}$ \\
\hline 3 & Video recording for classroom study & 0 & 2 & 33 & 56 & 91 & 3.50 & VH \\
\hline 4 & Video recording for self-study & 0 & 4 & 36 & 48 & 88 & 3.38 & $\mathrm{H}$ \\
\hline 5 & Audio recording through powerpoint presentation & 1 & 10 & 42 & 24 & 77 & 2.96 & $\mathrm{H}$ \\
\hline 6 & Video recording through powerpoint presentation & 1 & 8 & 45 & 24 & 78 & 3.00 & $\mathrm{H}$ \\
\hline 7 & $\begin{array}{l}\text { Audio recording integrated into exe-learning } \\
\text { software or other software (for interative classroom } \\
\text { study) }\end{array}$ & 1 & 4 & 42 & 36 & 83 & 3.19 & $\mathrm{H}$ \\
\hline 8 & $\begin{array}{l}\text { Video recording integrated into exe-learning } \\
\text { software or other software (for interactive classroom } \\
\text { study) }\end{array}$ & 1 & 4 & 42 & 36 & 83 & 3.19 & $\mathrm{H}$ \\
\hline 9 & Audio recording integrated into e-learning system & 1 & 8 & 36 & 36 & 81 & 3.12 & $\mathrm{H}$ \\
\hline \multirow[t]{2}{*}{10} & Video recording integrated into e-learning system & 1 & 4 & 45 & 32 & 82 & 3.15 & $\mathrm{H}$ \\
\hline & Rata-rata & & & & & & 3.23 & $\mathrm{H}$ \\
\hline
\end{tabular}


ing materials that existed before the study were conducted could not meet the students' need for listening material in accordance with their wishes, institutional goals, and the wishes of the graduate users.

Second, to minimize the gap between student needs and objective conditions in the field, a new syllabus was required based on the results of the theoretical studies in line with the results of needs analysis. A suitable syllabus is a mixed syllabus combining some of the best elements of a structural, structural syllabus, a syllabus based on the topic, theme, and text-based syllabus.

Third, a well-formulated syllabus developed into a listening teaching material in English. This teaching material was developed based on a genre-based approach and supported by the use of listening multimedia learning. This genre-based approach and the use of multimedia are chosen to be combined because basically these two are mutually supportive. Teaching materials that will be developed should cover those needs. These needs are obtained from the necessities, lack, and what students' wants.

\section{REFERENCES}

Al-Hammadi, F.S. (2011). The effectiveness of using a multimedia software in developing some listening skills among Saudi secondary school students'. Damascus University Journal, 27(3+4), 43-44.

Asma, B. D. (2013) The extent of implementing multimedia in teaching listening comprehension. Doctoral Thesis. Algeria: University of Biskra.,

Brinton, D. M. (2001). The use of media in language teaching in Teaching English as a Second or Foreign Language. Celce-Murcia, M. (Ed.). Boston: Heinle and heinle.

Chang, M.M., Lehman, J.D. (2012). Learning foreign language through an interactive multimedia program: An experimental study on the effects of relevance component of the ARCS Model. CALICO Journal. 20 (1).
Cunningsworth, A. (1995). Choosing your coursebook. Oxford: Heinemann.

Dost, I. N., Bohloulzadeh, G., \& Rahmatollahi, R. (2017) The effect of using podcast on listening comprehension among Iranian pre-intermediate EFL learners. International Journal of Applied Linguistics \& English Literature. 6(6), 57-68.

Feez, S. (1998). Text based syllabus design. Sydney: National Center for English Language Teaching and Research. Macquarie University.

Gall, M.D., Gall, J.P., \& Borg, W.R. (2003). Educational research: An introduction (seventh edition), Boston: Pearson Education.

Gilakjani, A. P., Ismail, H. N., \& Ahmadi., S. M. (2011). The effect of multimodal learning models on language teaching and learning. Theory and Practice in Language Study. 1(10), 1321-1327.

Ketsman, O. (2012). Technology-enhanced multimedia instruction in foreign language classroom: A mixed methods study. Doctoral Thesis. University of Nebraska.

Lebedev, M. Y., Koltakova, E.V., Khaleeva, O. N., \& Rusetskaya, M.N. (2017). Computer-assisted language learning for the development of listening skills: A case study of pre-university Russian as a foreign language. International Journal of Applied Linguistics \& English Literature. 6(1), 257-265.

Petrus, I. (2012). A portrat of the English course at a Faculty of Education in Sumatera. Conaplin Journal: Indonesian Journal of Applied Linguistics. 1(2), 62-74.

Richards, J.C. (2001). Curriculum development in language teaching. Cambridge: Cambridge University Press.

Sadeghi, B.; Hassani, M. T.; \& Noory, H. (2014). The effect of teachng different genre on listening comprehension performance of Irannian EFL students. Journal of Language Teaching and Research. 5(3), 517-523.

Woottipong, K. (2014). The effect of using video materials in the teaching of listening skills for university students. International Journal of Linguistics. 6(4). 